\title{
Citricoccus zhacaiensis sp. nov., isolated from a bioreactor for saline wastewater treatment
}

Correspondence

Min Wu

wumin@zju.edu.cn
Fan-Xu Meng, ${ }^{1}$ Xiao-Chen Yang, ${ }^{1}$ Pei-Song $\mathrm{Yu}^{2,3}$ Jian-Ming Pan, ${ }^{2,3}$
Chun-Sheng Wang, ${ }^{2,3}$ Xue-Wei $\mathrm{Xu}^{2,3}$ and Min $\mathrm{Wu}^{1}$

${ }^{1}$ College of Life Sciences, Zhejiang University, Hangzhou 310058, PR China

${ }^{2}$ Laboratory of Marine Ecosystem and Biogeochemistry, State Oceanic Administration, Hangzhou 310012, PR China

${ }^{3}$ Second Institute of Oceanography, State Oceanic Administration, Hangzhou 310012, PR China

A Gram-positive, neutrophilic, non-motile and non-spore-forming actinobacterium, strain $\mathrm{FS} 24^{\top}$, was isolated from a bioreactor treating salt-containing wastewater. This isolate grew in the presence of $0-15 \%(\mathrm{w} / \mathrm{v}) \mathrm{NaCl}$ and at $10-37{ }^{\circ} \mathrm{C}$. The optimum $\mathrm{NaCl}$ concentration for growth of $\mathrm{FS} 24^{\mathrm{T}}$ was $5 \%(\mathrm{w} / \mathrm{v})$ at $37{ }^{\circ} \mathrm{C}$ or $1 \%(\mathrm{w} / \mathrm{v})$ at $25^{\circ} \mathrm{C}$. Chemotaxonomic analysis revealed MK$9\left(\mathrm{H}_{2}\right)$ as the predominant menaquinone and the major cellular polar lipids were diphosphatidylglycerol, phosphatidylglycerol, phosphatidylinositol, four unknown glycolipids, two unknown phospholipids and an unknown lipid. The major fatty acids were anteiso- $\mathrm{C}_{15: 0 \text {, }}$ iso- $\mathrm{C}_{15: 0}$, iso- $\mathrm{C}_{16: 0}$ and anteiso- $\mathrm{C}_{17: 0}$. The genomic DNA $\mathrm{G}+\mathrm{C}$ content was $66.0 \mathrm{~mol} \%$. Phylogenetic analysis based on $16 \mathrm{~S}$ rRNA gene sequences indicated that strain $\mathrm{FS}_{2} 4^{\top}$ clustered with members of the genus Citricoccus, exhibiting high sequence similarity to the 16S rRNA gene sequences of the type strains of Citricoccus alkalitolerans (98.9\%) and Citricoccus muralis (98.8\%), respectively. The DNA-DNA relatedness values of strain $\mathrm{FS}_{2}{ }^{\top}$ to $\mathrm{C}$. alkalitolerans DSM $15665^{\top}$ and C. muralis DSM $14442^{\top}$ were 54 and $39 \%$, respectively. On the basis of phenotypic and genotypic data, strain $\mathrm{FS} 24^{\top}$ represents a novel species of the genus Citricoccus, for which the name Citricoccus zhacaiensis sp. nov. is proposed. The type strain is FS24 ${ }^{\top}$ $\left(=\right.$ CGMCC $1.7064^{\top}=$ JCM 15136 $\left.{ }^{\top}\right)$.
The genus Citricoccus was proposed by Altenburger et al. (2002a) and contains two species at the time of writing, Citricoccus muralis and Citricoccus alkalitolerans (Li et al., 2005). The members of the genus are Gram-positive cocci and have the following chemotaxonomic characteristics: MK-9 $\left(\mathrm{H}_{2}\right)$ as the predominant menaquinone, diphosphatidylglycerol, phosphatidylglycerol, phosphatidylinositol and several unknown lipids as the major polar lipids, and anteiso- $\mathrm{C}_{15: 0}$, anteiso- $\mathrm{C}_{17: 0}$, iso- $\mathrm{C}_{16: 0}$ and iso- $\mathrm{C}_{15: 0}$ as the major fatty acids (Altenburger et al., 2002a; Li et al., 2005).

Although the type strains of C. muralis and C. alkalitolerans displayed more than $99.5 \%$ 16S rRNA gene sequence similarity, the DNA-DNA relatedness value between them (56\%; Li et al., 2005) was lower than the threshold value of $70 \%$ for species delineation (Wayne et al., 1987). Besides,

Abbreviations: DPG, diphosphatidylglycerol; GL, unknown glycolipid; L, unknown polar lipid; MK, menaquinone; PG, phosphatidylglycerol; $\mathrm{Pl}$, phosphatidylinositol; PL, unknown phospholipid.

The GenBank/EMBL/DDBJ accession number for the 16S rRNA gene sequence of strain $F S 24^{\top}$ is EU305672.

A micrograph showing cells of strain $\mathrm{FS} 24^{\top}$ and the polar lipid profile of strain $\mathrm{FS} 24^{\top}$ are available with the online version of this paper. they showed some striking phenotypic differences, such as the type strain of $C$. alkalitolerans being alkalitolerant with optimum growth at $\mathrm{pH}$ 8.0-9.0, while that of $C$. muralis prefers neutral environments.

Strain FS24 ${ }^{\mathrm{T}}$ was isolated from the water-sludge mixture of a bioreactor treating saline wastewater generated from pickled vegetable production. A $100 \mu$ sample of the liquid mixture was spread on autoclaved wastewater-agar plates. The wastewater used was adjusted to $\mathrm{pH} 7.0$ with $\mathrm{NaOH}$ and autoclaved at $121{ }^{\circ} \mathrm{C}$ for $30 \mathrm{~min}$ beforehand. Plates were incubated aerobically at $30{ }^{\circ} \mathrm{C}$ for 5 days. Single colonies were picked up and purified by repeated restreaking on $\mathrm{ZC}$ medium. The $\mathrm{ZC}$ medium was designed according to the chemical composition analysis of the wastewater and contained (per litre distilled water) $10.0 \mathrm{~g}$ $\mathrm{NaCl}, 1.0 \mathrm{~g} \mathrm{KCl}, 2.0 \mathrm{~g} \mathrm{MgCl}_{2} \cdot 6 \mathrm{H}_{2} \mathrm{O}, 2.0$ g Casamino acids (Difco, Becton Dickinson) and $5.0 \mathrm{~g}$ Bacto yeast extract (Becton Dickinson), pH 7.5.

The optimum temperature for growth was determined in ZC broth at $4,10,20,25,30,37$ and $42{ }^{\circ} \mathrm{C}$. The optimal pH for growth was tested at $\mathrm{pH} 5-10$ (at intervals of $1.0 \mathrm{pH}$ unit) in $\mathrm{ZC}$ broth using the following buffers at a 
concentration of $25 \mathrm{mM}$ : MES (pH 5.0-6.0), PIPES ( $\mathrm{pH}$ 6.5-7.0), Tricine ( $\mathrm{pH} 7.5-8.5)$ and CAPSO (pH 9.010.0). The salt range for growth was determined in $\mathrm{ZC}$ broth with $0,0.5,1,3,5,7.5,10,15,20,25$ and $30 \%(\mathrm{w} / \mathrm{v})$ $\mathrm{NaCl}$ at $\mathrm{pH}$ 7.0. Both the $\mathrm{pH}$ and salt range tests were performed at $25{ }^{\circ} \mathrm{C}$ and $37{ }^{\circ} \mathrm{C}$. Anaerobic growth was tested in an atmosphere of $\mathrm{N}_{2}$ at $30{ }^{\circ} \mathrm{C}$ on $\mathrm{ZC}$ agar for 7 days. Cell morphology and motility were examined under an Olympus BX40 optical microscope and a JEOL JEM-1200EX transmission electron microscope.

Carbon source utilization and acid production tests were performed using the medium described by Kämpfer et al. (1991). Oxidase and catalase activity, $\mathrm{H}_{2} \mathrm{~S}$ production, hydrolysis of casein, starch, Tweens 20 and 80, tyrosine and urea, indole production and phenylalanine deamination were tested in ZC medium according to the methods given by Mata et al. (2002). Additional enzyme activities were determined by using API ZYM test kits (bioMérieux) according to the manufacturer's instructions. Sensitivity to antimicrobial agents was determined in $\mathrm{ZC}$ broth containing each antimicrobial agent at $50 \mathrm{mg}^{-1}$ for at least 2 days.

Genomic DNA was obtained by using the method described by Marmur (1961). The 16S rRNA gene was amplified and analysed as described previously (Xu et al., 2007). PCR products were cloned into the pMD19-T vector (TaKaRa) and then sequenced to determine the almost complete sequence of the $16 \mathrm{~S}$ rRNA gene. Phylogenetic affiliation to sequences available in GenBank was determined by using the BLAST program (Altschul et al., 1990). Sequence data were aligned by using CLUSTAL_X (Thompson et al., 1997). A phylogenetic tree was reconstructed by using the neighbourjoining method with the MEGA 4 program (Tamura et al., 2007). The topology of the phylogenetic tree was evaluated by using the bootstrap resampling method of Felsenstein (1985) with 1000 replicates.

Menaquinones were isolated by using the methods of Collins (1985) and analysed by HPLC. Polar lipids were extracted and examined by two-dimensional thin layer chromatography and were identified by using published procedures (Kamekura \& Kates, 1988; Xin et al., 2000). Fatty acid methyl esters obtained from cells grown on ZC agar for $36 \mathrm{~h}$ at $30{ }^{\circ} \mathrm{C}$ were analysed by using GC/MS (Kuykendall et al., 1988); the results were compared with the database of fatty acids in the MIDI Sherlock Microbial Identification system (MIDI). Cell wall extracts were prepared according to Kawamoto et al. (1981) and the qualitative analyses of amino acids in peptidoglycan hydrolysates were carried out by using HPLC as described by Janssen et al. (1986). Polyamine analysis was carried out as described by Altenburger et al. (1997).

The DNA G + C content was determined by using HPLC according to Mesbah et al. (1989). DNA-DNA hybridizations were performed by using the thermal denaturation and renaturation method of De Ley et al. (1970) as modified by Huß et al. (1983) by using a Beckman DU 800 spectrophotometer.
Cells of strain FS24 ${ }^{\mathrm{T}}$ were aerobic, Gram-positive, nonmotile and ellipsoidal, $0.6 \times 0.5 \mu \mathrm{m}$ in size. Flagella were not observed (Supplementary Fig. S1, available in IJSEM Online). Colonies were yellow-greenish, smooth, circular, convex, opaque and 1-2 $\mathrm{mm}$ in diameter after 2 days of incubation at $30{ }^{\circ} \mathrm{C}$ on $\mathrm{ZC}$ agar. Temperature and $\mathrm{pH}$ ranges for growth were $10-37{ }^{\circ} \mathrm{C}$ and $6.0-9.0$, respectively. Unlike C. alkalitolerans DSM $15665^{\mathrm{T}}$, no growth was observed at initial $\mathrm{pH}$ greater than 10.0. Strain $\mathrm{FS} 24^{\mathrm{T}}$ grew at $25{ }^{\circ} \mathrm{C}$ or $37{ }^{\circ} \mathrm{C}$ when $\mathrm{NaCl}$ concentrations were 0 to $15 \%$ (w/v), but the optimum $\mathrm{NaCl}$ concentration for growth differed with temperature. Optimum conditions for growth in ZC broth were 1 or $5 \%(\mathrm{w} / \mathrm{v}) \mathrm{NaCl}$ at 25 or $37{ }^{\circ} \mathrm{C}$, respectively. Strain $\mathrm{FS} 24^{\mathrm{T}}$ was able to grow on tryptone soy agar (Oxoid), PYES agar (Altenburger et al., 2002b) and CasMM agar (Altenburger et al., 1996) under aerobic conditions, but no growth was observed under anaerobic conditions.

The major fatty acids (greater than $1 \%$ ) of strain FS24 ${ }^{\mathrm{T}}$ were anteiso- $\mathrm{C}_{15: 0}(74.1 \%)$, anteiso- $\mathrm{C}_{17: 0}(16.5 \%)$, iso$\mathrm{C}_{15: 0}(5.5 \%)$ and iso- $\mathrm{C}_{16: 0}(1.7 \%)$. MK- $9\left(\mathrm{H}_{2}\right)$ was the predominant menaquinone with moderate amounts of MK-7 $\left(\mathrm{H}_{2}\right)$ and MK-8 $\left(\mathrm{H}_{2}\right)$. The major cellular polar lipids were diphosphatidylglycerol, phosphatidylglycerol, phosphatidylinositol, four unknown glycolipids, two unknown phospholipids and an unknown lipid (Supplementary Fig. S2). The peptidoglycan of strain FS $24^{\mathrm{T}}$ contained Ala, Gly, Glu and Lys in a molar ratio of $1.0: 0.5: 1.3: 1.0$. Spermidine was the major polyamine component along with various amounts of 1,3-diaminopropane, putrescine, cadaverine and spermine. The quinone system composition, polar lipid composition, major fatty acid profile, peptidoglycan and polyamine patterns of strain $\mathrm{FS} 24^{\mathrm{T}}$ were in accordance with the description of the genus Citricoccus.

There were some differences that distinguished strain FS24 ${ }^{\mathrm{T}}$ from other species of the genus Citricoccus. The proportion of anteiso- $\mathrm{C}_{15: 0}$ in strain $\mathrm{FS}_{2} 4^{\mathrm{T}}(74.1 \%)$ was greater than that of C. muralis DSM $14442^{\mathrm{T}}(55.6 \%)$, whereas the proportion of iso- $\mathrm{C}_{16: 0}$ in strain $\mathrm{FS} 24^{\mathrm{T}}(1.7 \%)$ was smaller than that of C. muralis DSM $14442^{\mathrm{T}}(8.0 \%)$ (Altenburger et al., 2002a). Physiological and biochemical properties which distinguished strain $\mathrm{FS} 24^{\mathrm{T}}$ from C. alkalitolerans DSM $15665^{\mathrm{T}}$ and C. muralis DSM $14442^{\mathrm{T}}$, such as the salt and $\mathrm{pH}$ ranges for growth, utilization of hydrocarbons and antibiotic sensitivity, are given in Table 1.

An almost complete 16S rRNA gene sequence for strain FS24 ${ }^{\mathrm{T}}$ (1490 nt) was obtained. Analysis of this sequence revealed that the isolate was phylogenetically related to the type strains of $C$. alkalitolerans and C. muralis, with similarities of 98.9 and $98.8 \%$, respectively. The similarity between the type strains of $C$. alkalitolerans and C. muralis was $99.6 \%$ (Li et al., 2005). The $16 \mathrm{~S}$ rRNA gene sequences of the three strains were quite similar; however, relative distance comparison on the phylogenetic tree indicated a closer relationship between $C$. alkalitolerans and C. muralis than between either of these species and strain FS24 ${ }^{\mathrm{T}}$ (Fig. 1). The DNA-DNA hybridization relatedness values of strain 
Table 1. Phenotypic characteristics differentiating strain $\mathrm{FS}_{2} 4^{\top}$ from Citricoccus muralis $\mathrm{DSM} 14442^{\top}$ and Citricoccus alkalitolerans DSM $15665^{\top}$

The following phenotypic characteristics are the same for all strains. Gram-positive, catalase-positive and oxidase-negative. Urease, tyrosinase, $\mathrm{H}_{2} \mathrm{~S}$ production and indole production are negative. Tweens 20 and 80, casein and starch are not decomposed. Nitrate is not reduced to nitrite. The following compounds are utilized as sole carbon sources: acetate, L-glutamate, gluconate, L-glutamine, isoleucine, malate, maltose, propionate, pyruvate, salicin, L-serine, succinate, sucrose, trehalose and L-valine. The following compounds are not utilized as sole carbon sources: adonitol, L-alanine, L-arginine, L-aspartate, cellobiose, L-cysteine, ethanol, formate, D-fructose, fumarate, glycerol, L-histidine, inositol, lactate, lactose, lysine, mannitol, D-mannose, melibiose, L-methionine, L-proline, raffinose, rhamnose, ribose, L-sorbitol, sorbose, xylitol or xylose. Acid production was not observed. In API ZYM tests, acid and alkaline phosphatases, $\alpha$-chymotrypsin, cystine arylamidase, esterase (C4), esterase lipase (C8), lipase (C14), leucine arylamidase, naphthol-AS-BI-phosphohydrolase, trypsin and valine arylamidase are detected. +, Positive; -, negative; R, resistant; s, susceptible.

\begin{tabular}{|c|c|c|c|}
\hline Characteristic & Strain FS24 ${ }^{\mathrm{T}}$ & C. muralis DSM $14442^{\mathrm{T}}$ & C. alkalitolerans DSM $15665^{\mathrm{T}}$ \\
\hline Growth in $15 \%(\mathrm{w} / \mathrm{v}) \mathrm{NaCl}$ & + & $-{ }^{\star}$ & $+\dagger$ \\
\hline Growth at $37^{\circ} \mathrm{C}$ & + & $-{ }^{\star}$ & $+\dagger$ \\
\hline$\alpha$-Glucosidase & + & + & - \\
\hline \multicolumn{4}{|l|}{ Utilization of: } \\
\hline L-Asparagine & - & + & + \\
\hline D-Galactose & - & + & - \\
\hline Glucose & - & + & + \\
\hline Glycine & - & + & - \\
\hline Malonate & + & + & - \\
\hline \multicolumn{4}{|l|}{ Antibiotic sensitivity } \\
\hline Rifampicin & $\mathrm{R}$ & $\mathrm{R}$ & s \\
\hline
\end{tabular}

${ }^{\star}$ Data from: Altenburger et al. (2002a).

$\dagger$ Data from: Li et al. (2005).

FS24 ${ }^{\mathrm{T}}$ with C. muralis DSM $14442^{\mathrm{T}}$ and C. alkalitolerans DSM $15665^{\mathrm{T}}$ were $39.3 \%$ (standard deviation $4.0 \%$ ) and $53.9 \%$ (standard deviation $5.0 \%$ ), respectively. These values were based on five replicates and were lower than the threshold value of $70 \%$ for species delineation (Wayne et al., 1987).

On the basis of phenotypic, chemotaxonomic and phylogenetic data that distinguish the isolate from other species of the genus Citricoccus, we suggest that strain FS24 ${ }^{\mathrm{T}}$ represents a novel species of the genus Citricoccus, for which the name Citricoccus zhacaiensis sp. nov. is proposed.

\section{Description of Citricoccus zhacaiensis sp. nov.}

Citricoccus zhacaiensis (zha.ca.i.en'sis. N.L. masc. adj. zhacaiensis pertaining to zhacai, the Chinese name for preserved vegetables).

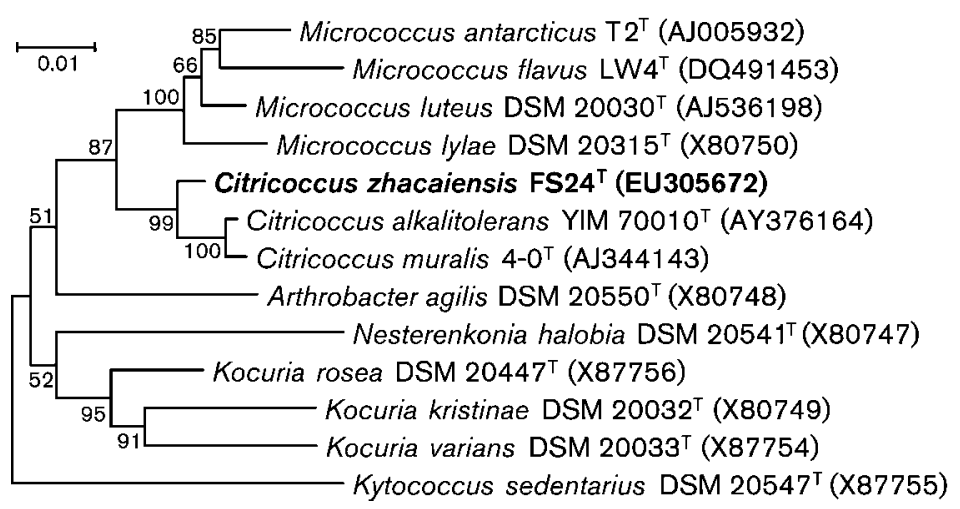

Fig. 1. Phylogenetic tree based on $16 \mathrm{~S}$ rRNA gene sequences showing the relationships of strain $\mathrm{FS}^{2} 4^{\top}$ and related taxa. The dendrogram was reconstructed by using the neighbourjoining method. Evolutionary distances were calculated according to the algorithm of the Kimura two-parameter model. Bootstrap values (based on 1000 replicates) greater than $50 \%$ are shown at nodes. Bar, 0.01 sequence dissimilarity per nucleotide position. 
Gram-positive, non-spore-forming and aerobic. Cells are non-motile and ellipsoidal, approximately $0.6 \times 0.5 \mu \mathrm{m}$ in size. Colonies are yellow-greenish, smooth, circular, convex, opaque and 1-2 $\mathrm{mm}$ in diameter. The temperature and $\mathrm{pH}$ range for growth are $10-37{ }^{\circ} \mathrm{C}$ (optimum 25$35{ }^{\circ} \mathrm{C}$ ) and $\mathrm{pH} 6.0-9.0$ (optimum $\mathrm{pH} 7.0$ ). Grows in the presence of $0-15 \%(\mathrm{w} / \mathrm{v}) \mathrm{NaCl}$, optimum at $1 \%(\mathrm{w} / \mathrm{v})$ below $25{ }^{\circ} \mathrm{C}$ or $5 \%(\mathrm{w} / \mathrm{v})$ below $37{ }^{\circ} \mathrm{C}$. Catalase-positive and oxidase-negative. Casein, starch, Tweens 20 and 80 and urea are not decomposed. Nitrate reduction, $\mathrm{H}_{2} \mathrm{~S}$ production, phenylalanine deamination, indole production and tyrosinase activity are negative. The following constitutive enzyme activities are detected in API ZYM tests: acid and alkaline phosphatases, $\alpha$-chymotrypsin, cystine arylamidase, esterase (C4), esterase lipase (C8), $\alpha$-glucosidase, lipase (C14), leucine arylamidase, naphthol-AS-BIphosphohydrolase, trypsin and valine arylamidase. $\beta$-Fucosidase, $\alpha$ - and $\beta$-galactosidases, $\beta$-glucosidase, $\beta$ glucuronidase, $N$-acetyl- $\beta$-glucosaminidase and $\alpha$-mannosidase are not observed. Chemo-organotrophic. The following compounds are utilized as sole carbon sources: acetate, citrate, L-glutamate, gluconate, L-glutamine, isoleucine, malate, malonate, maltose, propionate, pyruvate, salicin, L-serine, succinate, sucrose, trehalose and L-valine. The following compounds are not utilized as sole carbon sources: adonitol, L-alanine, L-arabinose, L-arginine, Lasparagine, L-aspartate, cellobiose, L-cysteine, ethanol, formate, D-fructose, fumarate, D-galactose, glucose, glycerol, glycine, L-histidine, inositol, lactate, lactose, lysine, mannitol, D-mannose, melibiose, L-methionine, L-proline, raffinose, rhamnose, ribose, L-sorbitol, sorbose, starch, xylitol or xylose. Acid production was not observed. Susceptible to cefotaxime, chloramphenicol, erythromycin, neomycin, novobiocin, polymyxin B and tetracycline, but not to kanamycin, nalidixic acid, nitrofurantoin, nystatin, rifampicin or streptomycin. The predominant menaquinone is MK- $9\left(\mathrm{H}_{2}\right)$. The major cellular polar lipids are diphosphatidylglycerol, phosphatidylglycerol, phosphatidylinositol, four unknown glycolipids, two unknown phospholipids and an unknown lipid. The major fatty acids are anteiso- $\mathrm{C}_{15: 0}$, iso- $\mathrm{C}_{15: 0}$, iso- $\mathrm{C}_{16: 0}$ and anteiso$\mathrm{C}_{17: 0}$. The cell wall amino acids are alanine, glycine, glutamic acid and lysine. Spermidine is predominant in the polyamine pattern. The DNA $\mathrm{G}+\mathrm{C}$ content of the type strain is $66.0 \mathrm{~mol} \%$.

The type strain, FS24 ${ }^{\mathrm{T}}\left(=\right.$ CGMCC $1.7064^{\mathrm{T}}=\mathrm{JCM} 15136^{\mathrm{T}}$ ), was isolated from a bioreactor treating wastewater generated from preserved vegetable production.

\section{Acknowledgements}

We thank Jean Euzéby for his help with the specific etymology and nomenclature. This work was supported by grants from the Ministry of Science and Technology of China (973 Program, 2004CB719604-3; 863 Program, 2007AA021305), the National Natural Science Foundation of China $(40806066,30670048)$ and Key Project of Zhejiang Science and Technology (2006C13053).

\section{References}

Altenburger, P., Kämpfer, P., Makristathis, A., Lubitz, W. \& Busse, H.-J. (1996). Classification of bacteria isolated from a medieval wall painting. J Biotechnol 47, 39-52.

Altenburger, P., Kämpfer, P., Akimov, V. N., Lubitz, W. \& Busse, H.-J. (1997). Polyamine distribution in actinomycetes with group $B$ peptidoglycan and species of the genera Brevibacterium, Corynebacterium, and Tsukamurella. Int J Syst Bacteriol 47, 270-277.

Altenburger, P., Kämpfer, P., Schumann, P., Steiner, R., Lubitz, W. \& Busse, H.-J. (2002a). Citricoccus muralis gen. nov., sp. nov., a novel actinobacterium isolated from a medieval wall painting. Int J Syst Evol Microbiol 52, 2095-2100.

Altenburger, P., Kämpfer, P., Schumann, P., Vybiral, D., Lubitz, W. \& Busse, H.-J. (2002b). Georgenia muralis gen. nov., sp. nov., a novel actinobacterium isolated from a medieval wall painting. Int J Syst Evol Microbiol 52, 875-881.

Altschul, S. F., Gish, W., Miller, W., Myers, E. W. \& Lipman, D. J. (1990). Basic local alignment search tool. J Mol Biol 215, 403-410.

Collins, M. D. (1985). Isoprenoid quinone analysis in classification and identification. In Chemical Methods in Bacterial Systematics, pp. 267-287. Edited by M. Goodfellow \& D. E. Minnikin. London: Academic Press.

De Ley, J., Cattoir, H. \& Reynaerts, A. (1970). The quantitative measurement of DNA hybridization from renaturation rates. Eur $J$ Biochem 12, 133-142.

Felsenstein, J. (1985). Confidence limits on phylogenies: an approach using the bootstrap. Evolution 39, 783-791.

Huß, V. A. R., Festl, H. \& Schleifer, K. H. (1983). Studies on the spectrophotometric determination of DNA hybridization from renaturation rates. Syst Appl Microbiol 4, 184-192.

Janssen, P. S. L., van Nispen, J. W., Melgers, P. A. T. A., van den Bogaart, H. W. M., Hamelinck, R. L. A. E. \& Goverde, B. C. (1986). HPLC analysis of phenylthiocarbamyl (PTC) amino acids I. Evaluation and optimization of the procedure. Chromatographia 22, 345-350.

Kamekura, M. \& Kates, M. (1988). Lipids of halophilic archaebacteria. In Halophilic bacteria II, pp. 25-54. Edited by F. Rodriguez-Valera. Boca Raton, FL: CRC Press.

Kämpfer, P., Steiof, M. \& Dott, W. (1991). Microbiological characterization of a fuel-oil contaminated site including numerical identification of heterotrophic water and soil bacteria. Microb Ecol 21, 227-251.

Kawamoto, I., Oka, T. \& Nara, T. (1981). Cell wall composition of Micromonospora olivoasterospora, Micromonospora sagamiensis, and related organisms. J Bacteriol 146, 527-534.

Kuykendall, L. D., Roy, M. A., O’Neill, J. J. \& Devine, T. E. (1988). Fatty acids, antibiotic resistance, and deoxyribonucleic acid homology groups of Bradyrhizobium japonicum. Int J Syst Bacteriol 38, 358-361.

Li, W.-J., Chen, H.-H., Zhang, Y.-Q., Kim, C.-J., Park, D.-J., Lee, J.-C., Xu, L.-H. \& Jiang, C.-L. (2005). Citricoccus alkalitolerans sp. nov., a novel actinobacterium isolated from a desert soil in Egypt. Int J Syst Evol Microbiol 55, 87-90.

Marmur, J. (1961). A procedure for the isolation of deoxyribonucleic acid from microorganisms. J Mol Biol 3, 208-218.

Mata, J. A., Martínez-Cánovas, J., Quesada, E. \& Béjar, V. (2002). A detailed phenotypic characterisation of the type strains of Halomonas species. Syst Appl Microbiol 25, 360-375.

Mesbah, M., Premachandran, U. \& Whitman, W. B. (1989). Precise measurement of the $\mathrm{G}+\mathrm{C}$ content of deoxyribonucleic acid by highperformance liquid chromatography. Int J Syst Bacteriol 39, 159-167. 
Tamura, K., Dudley, J., Nei, M. \& Kumar, S. (2007). MEGA4: molecular evolutionary genetics analysis (MEGA) software version 4.0. Mol Biol Evol 24, 1596-1599.

Thompson, J. D., Gibson, T. J., Plewniak, F., Jeanmougin, F. \& Higgins, D. G. (1997). The CLUSTAL_X windows interface: flexible strategies for multiple sequence alignment aided by quality analysis tools. Nucleic Acids Res 25, 4876-4882.

Wayne, L. G., Brenner, D. J., Colwell, R. R., Grimont, P. A. D., Kandler, O., Krichevsky, M. I., Moore, L. H., Moore, W. E. C., Murray, R. G. E. \& other authors (1987). International Committee on Systematic Bacteriology. Report of the ad hoc committee on reconciliation of approaches to bacterial systematics. Int $J$ Syst Bacteriol 37, 463-464.

Xin, H., Itoh, T., Zhou, P., Suzuki, K., Kamekura, M. \& Nakase, T. (2000). Natrinema versiforme sp. nov., an extremely halophilic archaeon from Aibi salt lake, Xinjiang, China. Int J Syst Evol Microbiol 50, 1297-1303.

Xu, X.-W., Wu, Y.-H., Zhou, Z., Wang, C.-S., Zhou, Y.-G., Zhang, H.-B., Wang, Y. \& Wu, M. (2007). Halomonas saccharevitans sp. nov., Halomonas arcis sp. nov. and Halomonas subterranea sp. nov., halophilic bacteria isolated from hypersaline environments of China. Int J Syst Evol Microbiol 57, 1619-1624. 